НАУКОВИЙ ВІСНИК

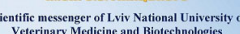

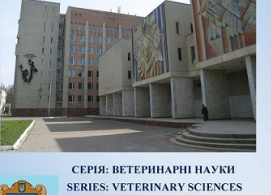

:RIES: VETERINARY SCIENC
Науковий вісник Дьвівського національного університету ветеринарної медицини та біотехнодогій імені С.З. Гжицького. Серія: Ветеринарні науки

\author{
Scientific Messenger of Lviv National University
} of Veterinary Medicine and Biotechnologies. Series: Veterinary sciences

UDC 619:636.7:616.995.192.6:616-06:616.151:615.225.2-3

\title{
Pathogenetic therapy of vascular-platelet hemostasis disorders in canine acute spontaneous babesiosis
}

\author{
O. A. Dubova, A. O. Rudchenko, D. V. Feshchenko, A. A. Dubovyi, I. V. Chala, O. A. Zghozinska
}

Polissya National University, Zhytomyr, Ukraine

Article info

Received 14.07.2021

Received in revised form 16.08.2021

Accepted 17.08.2021

Polissya National Univercity Korolyova Str., 39, Zhytomyr 10025, Ukraine. Tel.: +38-098-788-55-95 E-mail: oxdubova@gmail.com
Dubova, O. A., Rudchenko, A. O., Feshchenko, D. V., Dubovyi, A. A., Chala, I. V., \& Zghozinska, O. A. (2021). Pathogenetic therapy of vascular-platelet hemostasis disorders in canine acute spontaneous babesiosis. Scientific Messenger of Lviv National University of Veterinary Medicine and Biotechnologies. Series: Veterinary sciences, 23(103), 96-102. doi: 10.32718/nvlvet10313

The article presents the results of a study of the vascular-platelet hemostasis disorders processes in complications of canine acute spontaneous babesiosis, as well as a clinical trial of plasma substitute infusion for the purpose of identified disorders pathogenetic therapy. It was found that acute spontaneous Babesiosis is accompanied by complications in the form of subcompensated shock and a thrombogenic link of disseminated intravascular coagulation syndrome (DIC). This determines the potential risk of complications with a cautious prognosis. The basis for the diagnosis of complications is the establishment of the following changes: a significant deficit in the volume of circulating blood (a decrease in the hematocrit value, the volume of circulating plasma, the volume of circulating red blood cells, the specific volume of circulating blood), as well as significant changes in the functioning of the vascular-platelet link of hemostasis thrombocytopenia against the background of an increase in the spontaneous aggregation ability of platelets and red blood cells, an increase in the wetting index of the vascular wall, which determines the thrombogenic state, and pronounced thrombocytopenia indicates the consumption of these shaped elements in blood clots. The described changes indicate the development of subcompensated shock and the thrombogenic component of DIC syndrome. Given the prognostic danger of established complications, there is a need for pathogenetic therapy of severe conditions. Infusions of plasma substitute solutions have been proposed to eliminate shock phenomena and the thrombogenic state of disseminated intravascular coagulation syndrome. A clinical trial of intravenous administration of Rheosorbylact solution and a mixture of Rheosorbylact with Dipyridamole was conducted in a comparative aspect. It is shown that a mixture of Rheosorbylact $100 \mathrm{ml}$ and Dipyridamole solution $0.5 \% 4 \mathrm{ml}$ in the form of infusions at a dose of $5 \mathrm{ml} / \mathrm{kg}$ of animal body weight per day for 3 days can bring hemodynamic parameters and parameters of vascular-platelet hemostasis to physiological ones within 48 hours compared to an infusion of Rheosorbylact solution in its pure form. The synergy of the crystalloid solution of Rheosorbylact and the disaggregating vasodilator Dipyridamole enhances the disaggregating effect of both drugs, and the crystalloid solution itself is able to restore the lost volume of circulating blood.

Key words: babesiosis, vascular-platelet hemostasis, Rheosorbylact, Dipyridamole, infusions, thrombocytopenia, circulating blood volume deficit, platelet aggregation, shock, DIC syndrome.

\section{Патогенетична терапія розладів судинно-тромбоцитарного гемостазу за гострого спонтанного бабезіозу собак}

\author{
О. А. Дубова, А. О. Рудченко, Д. В. Фещенко, А. А. Дубовий, І. В. Чала, О. А. Згозінська
}

Поліський начіональний університет, м. Житомир, Украӥна

У статті наведені результати дослідження процесів порушення судинно-тромбоцитарного гемостазу за ускладнень гострого спонтанного бабезіозу собак, а також клінічного випробовування інфузії плазмозамінників з метою патогенетичної терапї̈ виявлених порушень. Встановлено, щзо гострий спонтанний бабезіоз супроводжується ускладненнями у вигляді субкомпенсованого 
иоку та тромбогенної ланки синдрому дисемінованого внутрішньосудинного згортання крові (ДВЗ). Це визначає потениійну небезпеку ускладнень з обережним прогнозом. Підставою для діагностики ускладнень є встановлення таких змін: достовірний дефіцุит об 'єму циркулюючої крові (зниження гематокритної величини, об 'єму цииркулюючої плазми, об'єму циркулюючих еритроцитів, питомого об'єму циркулюючої крові), а також достовірні зміни у показниках функціонування судинно-тромбоцитарної ланки гемостазу - тромбочитопенія на фоні збільшення спонтанної агрегачійної здатності тромбочитів $i$ еритрочитів, зростання індексу змочування судинної стінки, шчо визначає тромбогенний стан, а виражена тромбоцитопенія свідчить про спожсвання цих формених елементів у тромби. Описані зміни вказують на розвиток субкомпенсованого шоку та тромбогенний компонент синдрому ДВЗ. Враховуючи прогностичну небезпеку встановлених ускладнень, виникає необхідність патогенетичної терапії важких станів. Задля усунення шокових явищ і тромбогенного стану синдрому дисемінованого внутрішньосудинного згортання крові запропоновано інфузї розчинів плазмозамінників. Проведено клінічне випробовування внутрішньовенних введень розчину Реосорбілакту та суміші Реосорбілакту з Дипіридамолом у порівняльному аспекті. Показано, шо суміш Реосорбілакту 100 мл та розчину Дипіридамолу 0,5\% 4 мл у вигляді інфузій в дозі 5 мл/кг маси тіла тварини на день впродовж 3-х діб здатна привести гемодинамічні показники та параметри судинно-тромбочитарного гемостазу до фізіологічних впродовж 48 годин порівняно з інфузією розчину Реосорбілакту у чистому вигляді. Синергізм кристалоїдного розчину Реосорбілакту та дезагреганту-вазодилататору Дипіридамолу посилює дезагрегаційний ефект обох препаратів, а сам кристалоїдний розчин здатний відновити втрачений об’ єм ичиркулюючої крові.

Ключові слова: бабезіоз, судинно-тромбоцитарний гемостаз, Реосорбілакт, Дипіридамол, інфузї, тромбоцитопенія, дефіцит ОЦК, агрегаиія тромбоиитів, шок, синдром ДВЗ.

\section{Ветуп}

Зона Центрального Полісся України має кліматичні та ландшафтні умови, що $є$ ідеальними для існування біотопів іксодових кліщів - векторів різних захворювань 3 трансмісивним механізмом передачі збудника. Для собак регіону найбільш розповсюдженим кровопротозойним захворюванням є бабезіоз, який щорічно наносить невиправну шкоду здоров'ю тварин та часто приводить до летальних наслідків (Köster et al., 2015).

Збудниками хвороби у регіоні є великі форми Babesia spp. (B. canis G. P. Piana et B. Galli-Valerio, 1895, B. vogeli Reichenow, 1937). Обидва види космополітні, мають відмінні імунологічні властивості та різняться за вірулентністю. Основними переносниками у зоні Центрального Полісся виступають кліщі родів Dermacentor Koch, 1844, Ixodes Latreille, 1795 (Irwin, 2010; Köster et al., 2015).

Бабезіоз як кровопротозойне захворювання має надзвичайно важкі наслідки для організму тварини. Паразитуючи у червоних кров'яних клітинах, збудники приводять до їх руйнування. Недостатність киснепостачання до різних органів і тканин тягне за собою ланцюг патологічних процесів. Передусім страждає мікроциркуляторне русло тканин, що тягне за собою цілу низку важких ускладнень. Насамперед на вплив патогенного стимулу реагує система гемостазу, основна функція якої - забезпечення адекватного кровотоку у судинному руслі та запобігання формуванню тромбозів і кровотеч (Köster et al., 2015; Holovakha et al., 2018; Dubova et al., 2020).

Судинно-тромбоцитарний гемостаз $є$ первинною ланкою у системі гемостазу. Він зумовлений змінами судинної стінки, а також впливом формених елементів крові, спрямованих на зупинку кровотечі. Механізм цього різновиду гемостазу реалізується завдяки спазму судин, формуванню агрегатів тромбоцитів, еритроцитів, що прилипають до пошкодженого ендотелію, склеюються між собою та утворюють тромб. В структурі такого тромбу переважають тромбоцити, тому він називається "білий тромб” (Kutafina \& Zavalishina, 2012).
За фізіологічних умов судинно-тромбоцитарний гемостаз відбувається постійно і ліквідує мікропошкодження ендотелію завдяки складним механізмам взаємодії тромбоцитів та судинної стінки, виділенню факторів здійснення репаративної функції (Bennett et al., 2009; Kutafina \& Zavalishina, 2012).

За патологічних умов, особливо за впливу потужних руйнівних факторів, судинно-тромбоцитарний гемостаз активується потужно, а наслідком такої активації виступає бурхливий розвиток гемостатичної відповіді, що врешті-решт переходить у потужну гемостазіопатію - диссеміноване внутрішньосудинне згортання крові, яка може мати фатальні наслідки для життя тварини (Dubova, 2016; Wiseman et al., 2013; Tyutyumova et al., 2019). Таким чином, своєчасна діагностика змін та адекватна схема патогенетичної терапії є надзвичайно важливими.

Мета роботи - вивчити особливості змін судинно-тромбоцитарної ланки гемостазу за гострого спонтанного бабезіозу собак та розробити схему патогенетичної терапії встановлених патологічних процесів.

\section{Матеріал і методи досліджень}

Дослідження проводили у 2021 році на базі навчально-науково-виробничої клініки ветеринарної медицини Поліського національного університету, м. Житомир, Україна.

Усі маніпуляції з тваринами проводили відповідно до Європейської конвенції про захист хребетних тварин, які використовуються для експериментальних i наукових цілей (Official Journal of the European Union L276/33, 2010).

Дослідна група - собаки віком 2-4 р., масою 2030 кг, хворі на гострий спонтанний бабезіоз (n = 20).

Контрольна група - клінічно здорові собаки за принципом пар-аналогів $(\mathrm{n}=20)$.

Клінічні дослідження проводили загальними методами (Tvedten, 2004). Підстава для встановлення діагнозу - виявлення збудників у фіксованих мазках крові, забарвлених за методом Романовського-Гімзи. Було проведено родову типізацію Babesia spp. за розміром грушоподібних форм, що перевищувала радіус 
еритроциту (Eichenberger et al., 2016; Kirtz, 2016). Видову типізацію збудників не встановлювали.

Для лабораторних досліджень використовували нативну кров, стабілізовану антикоагулянтом розчином натрію цитрату 3,8 \%, який додавали у співвідношенні 1:10 до об'єму проби крові.

Кількість тромбоцитів визначали на гематологічному аналізаторі Mindray BC-3600. Гематокритну величину досліджували мікроцентрифугуванням.

Оцінку судинно-тромбоцитарної ланки гемостазу проводили за визначенням спонтанної агрегаційної здатності тромбоцитів та еритроцитів методом струшування за Н. I. Тарасовою (Jarec \& Novikova, 2014).

Індекс змочування судинної стінки вираховували як відношення часу спонтанного згортання нативної крові за Li-White до силіконового часу згортання (метод Жака, Фіднера i Макдональда) на підставі тромбоеластографічної реєстрації процесу у силіконованій кюветі (Jarec \& Novikova, 2014).

Гемодинамічні параметри включали визначення об'єму циркулюючої крові та іiї компонентів методом розведення синього Еванса Т-1824 та розрахунок ступеня крововтрати за формулою Moore (1) (Soroka et al., 2005):

$$
B L V=C B V * \frac{\left(H c t_{c o n}-H c t_{a x p}\right)}{H c t_{c o n}}
$$

де: BLV - дефіцит об'єму крові, мл;

CBV - об'єм циркулюючої крові у контрольної групи, $\mathrm{ml}$;

Hct $_{\text {con }}$ - гематокритна величина контрольної групи тварин, л/л;

Hct $_{\text {exp }}$ - гематокритна величина дослідної групи тварин, л/л.
3 метою специфічної терапії усім хворим собакам використовували препарат Імкар-120 виробництва НВФ “Бровафарма”, Україна, згідно до настанови.

Для проведення клінічного випробовування патогенетичної терапії корекції судинно-тромбоцитарного гемостазу нами було створено 2 групи:

І дослідна група $(\mathrm{n}=10)$ - внутрішньовенна інфузія плазмозамінного розчину Реосорбілакт у дозі 5 мл/кг маси тіла тварини в день.

II дослідна група $(\mathrm{n}=10)$ - внутрішньовенна інфузія суміші розчинів складу Реосорбілакт 100 мл та Дипіридамол 0,5 \% 4 мл - у дозі 5 мл/кг маси тіла тварини в день впродовж 3-х діб.

Урахування ефективності застосування патогенетичної терапії проводили через 24,48 та 72 години за оцінкою основних дослідних показників.

Статистичну обробку отриманих результатів проводили з використанням розподілу Фішера (ANOVA). Достовірність оцінювали за F-критерієм на довірчому рівні $\mathrm{P}<0,05$.

\section{Результати та їх обговорення}

За розвитку гострого спонтанного бабезіозу в організмі собаки відбуваються потужні патоморфологічні зміни, що стосуються різних органів і систем. У попередніх роботах (Dubova, 2016; Dubova et al., 2020) було показано розвиток шокового стану середнього ступеня, що має субкомпенсований характер. Отже, вплив збудника є шокогенним за характером своєї вірулентності.

Критеріями визначення ступеня шоку є показники гемодинамічних розладів, які демонструють ступінь дефіциту об’єму циркулюючої крові (ОЦК) (табл. 1).

\section{Таблиця 1}

Показники об’єму циркулюючої крові та її елементів у собак, хворих на гострий спонтанний бабезіоз

\begin{tabular}{lcc}
\hline \multicolumn{1}{c}{ Показники } & Дослідна група & Контрольна група \\
\hline Об’єм циркулюючої плазми (ОЦП), мл & $1901 \pm 111^{* * *}$ & $2506 \pm 234$ \\
Об’єм циркулюючих еритроцитів (ОЦЕ), мл & $772,3 \pm 56,3^{* * *}$ & $1584 \pm 208$ \\
Об’єм циркулюючої крові (ОЦК), мл & $2655 \pm 247 * * *$ & $4075 \pm 182$ \\
Питомий об'єм циркулюючої крові (питОЦК), мл/кг & $127,5 \pm 6,2^{* * *}$ & $192,3 \pm 12,6$ \\
\% ОЦК від маси тіла & $10,7 \pm 1,0 * * *$ & $16,3 \pm 1,1$ \\
Гематокритна величина, л/л & $0,29 \pm 0,03 * * *$ & $0,39 \pm 0,07$ \\
\hline
\end{tabular}

Примітка: у цій та наступних таблицях статистично вірогідні різниці враховували порівняно 3 контрольною групою: $* * * \mathrm{P}<0,001$

У патогенезі шокового стану вплив етіологічних чинників насамперед зачіпає реакцію судин, особливо у мікроциркуляторному ложі органів (Levi, 2018). Відбувається стимуляція адгезивних та агрегаційних функцій формених елементів крові, а також фізикохімічні показники самої інтими, що сприяє тромбоутворенню. Означені зміни описуються показниками судинно-тромбоцитарного гемостазу (табл. 2).

\section{Таблиця 2}

Стан судинно-тромбоцитарної ланки гемостазу собак, хворих на гострий спонтанний бабезіоз

\begin{tabular}{lcc}
\hline \multicolumn{1}{c}{ Показники } & Дослідна група & Контрольна група \\
\hline Тромбоцити, Г/л & $166,2 \pm 26,8^{* * *}$ & $292,4 \pm 32,6$ \\
Спонтанна агрегаційна здатність тромбоцитів, \% & $54,3 \pm 6,8^{* * *}$ & $17,7 \pm 1,2$ \\
Спонтанна агрегаційна здатність еритроцитів, \% & $40,3 \pm 3,6^{* * *}$ & $9,2 \pm 1,2$ \\
Індекс змочування судинної стінки & $0,88 \pm 0,08^{* * *}$ & $0,286 \pm 0,03$ \\
\hline
\end{tabular}


Аналізуючи показники (табл. 1, 2), встановили значний дефіцит ОЦК (1420 мл), який становить 34 \%. За умов відсутності зовнішньої кровотечі крововтрата зумовлена виходом формених елементів у агрегати, а плазми крові - у інтерстиціальні тканини з розвитком ïх набряку (Birkhahn et al., 2005; Pacagnella et al., 2013) Встановлений дефіцит ОЦК характеризує шок середньої інтенсивності зі стійкою тенденцією до незворотності (Schorn, 2010; Guly et al., 2011; Nathan et al., 2016).

Значне достовірне збільшення спонтанної агрегаційної здатності еритроцитів та тромбоцитів (Р $<0,001)$ характеризує тромбогенний стан, що виступає складовою ланкою синдрому ДВ3 (Kutafina \& Zavalishina, 2012; Levi, 2018). Значна тромбоцитопенія (Р < 0,001) свідчить про вихід цих формених елементів у тромби (тромбоцитопенія споживання) (Levi, 2018).

Значно збільшений індекс змочування судинної стінки $(\mathrm{P}<0,001)$ відображає Z-потенціал інтими судин щодо адвентиції і характеризує такий стан інтими, за якого формені елементи до неї рясно прилипають, тимчасом як за фізіологічних умов існує такий заряд інтими, що відштовхує надлишок тромбоцитів“годувальників" інтими своїми клітинними факторами (Kutafina \& Zavalishina, 2012; Levi, 2018).

Таким чином, встановлені зміни у гемодинамічних та гемореологічних показниках хворих на гострий спонтанний бабезіоз собак визначають субкомпенсований шоковий стан $з$ тенденцією до незворотності, а також тромбогенний стан $з$ тромбоцитопенією споживання, що свідчить про розвиток синдрому ДВЗ. Такі ускладнення за своєю патогенетичною сутністю є небезпечними та непередбачуваними, а отже - вимагають негайного застосування засобів патогенетичної терапії для недопущення переходу шокового стану та синдрому ДВЗ до незворотних стадій.

Ліквідація шокових явищ може бути досягнута шляхом відновлення ОЦК. Це реалізується шляхом інфузії розчинів-плазмозамінників, здатних покращити волемічні параметри (Dubova et al., 2020). Водно- час необхідно припинити розвиток тромбогенного стану як ланки ДВ3. Відомо (Dubova, 2016), що шок і ДВ3 патогенетично тісно пов'язані між собою, тому i вплив на обидва процеси має шанс припинення бурхливих ускладнень. Отже, доцільним $є$ використання додатково засобів-дезагрегантів, які можуть бути застосовані інфузійно у складі плазмозамінників.

Для клінічного випробовування нами було застосовано інфузії Реосорбілакту - плазмозамінного розчину, що має виражені дезагрегантні властивості (Dubova et al., 2020) та суміші розчинів Реосорбілакту та Дипіридамолу 0,5 \% у порівняльному аспекті. Результати наведені на рис. 1-4.

3 отриманих даних видно, що інфузія суміші розчинів Реосорбілакту та Дипіридамолу має значно виражений дезагрегаційний ефект порівняно з інфузією чистого Реосорбілакту.

Так, спонтанна агрегаційна здатність тромбоцитів та еритроцитів за застосування суміші розчинів знижується швидше і повертається до фізіологічних показників за 48 годин (за використання Реосорбілакту за 72 години). Аналогічна динаміка виявлена і у зниженні показників індексу змочування судинної стінки, відновлення питомого ОЦК, кількості тромбоцитів. Такі зміни свідчать про ефективніше вивільнення тромбоцитів $з$ процесу агрегації, ефективне їх використання судинною стінкою для репаративних процесів. Отже, застосування Дипіридамолу у складі плазмозаміннику для інфузій значно поліпшує дезагрегаційні властивості суміші, що сприяло пришвидшенню досягнення встановленої мети щодо ліквідації шокового стану та розвитку синдрому ДВЗ.

Дипіридамол має широке застосування у гуманній медицині. За механізмом фармакологічного впливу речовина належить до вазодилататорів та дезагрегантів. Препарат $є$ сумісним з кристалоїдними розчинами, що й дозволило нам використати суміш лікарських засобів. Завдяки синергізму отримано збільшення дезагрегаційного впливу суміші, що дало можливість скоротити час відновлення основних показників судинно-тромбоцитарного гемостазу.

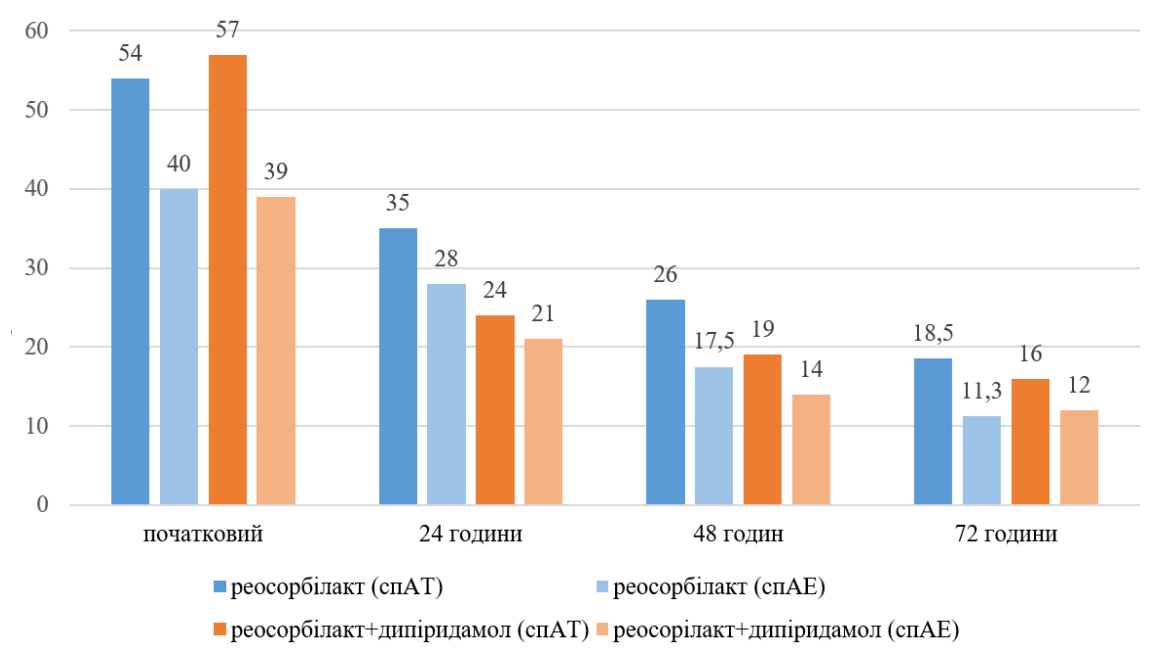

Рис. 1. Динаміка змін спонтанної агрегаційної здатності тромбоцитів (спАТ), \%, та спонтанної агрегаційної здатності еритроцитів (спАЕ), \%, за застосування розчинів плазмозамінників 


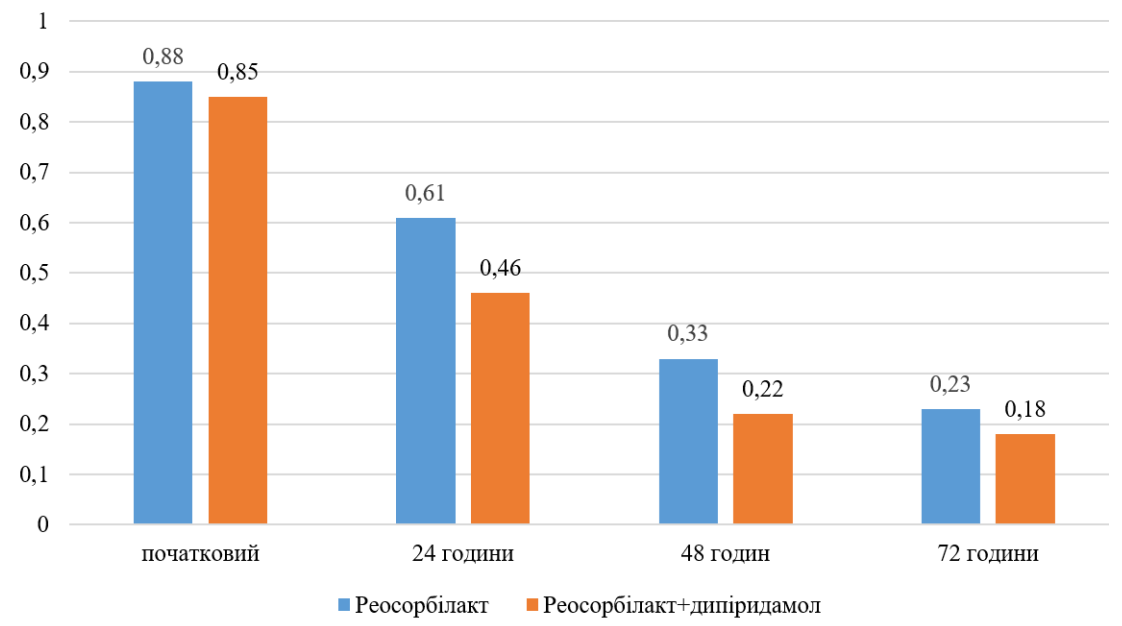

Рис. 2. Динаміка змін індексу змочування судинної стінки за застосування розчинів плазмозамінників

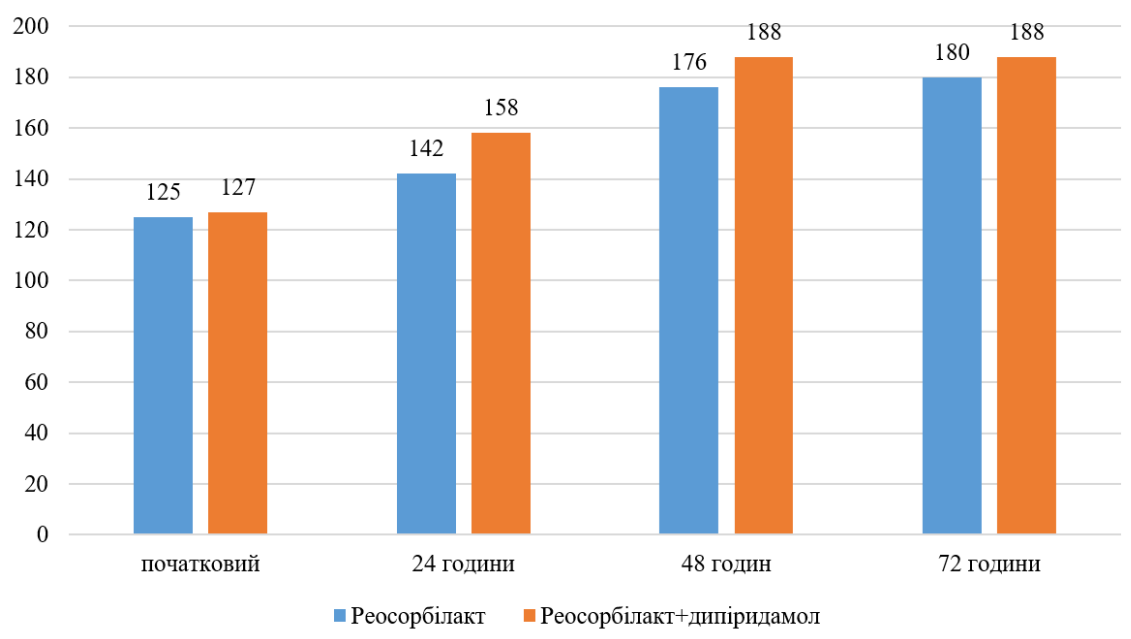

Рис. 3. Динаміка змін питомого ОЦК, мл/кг, за застосування розчинів плазмозамінників

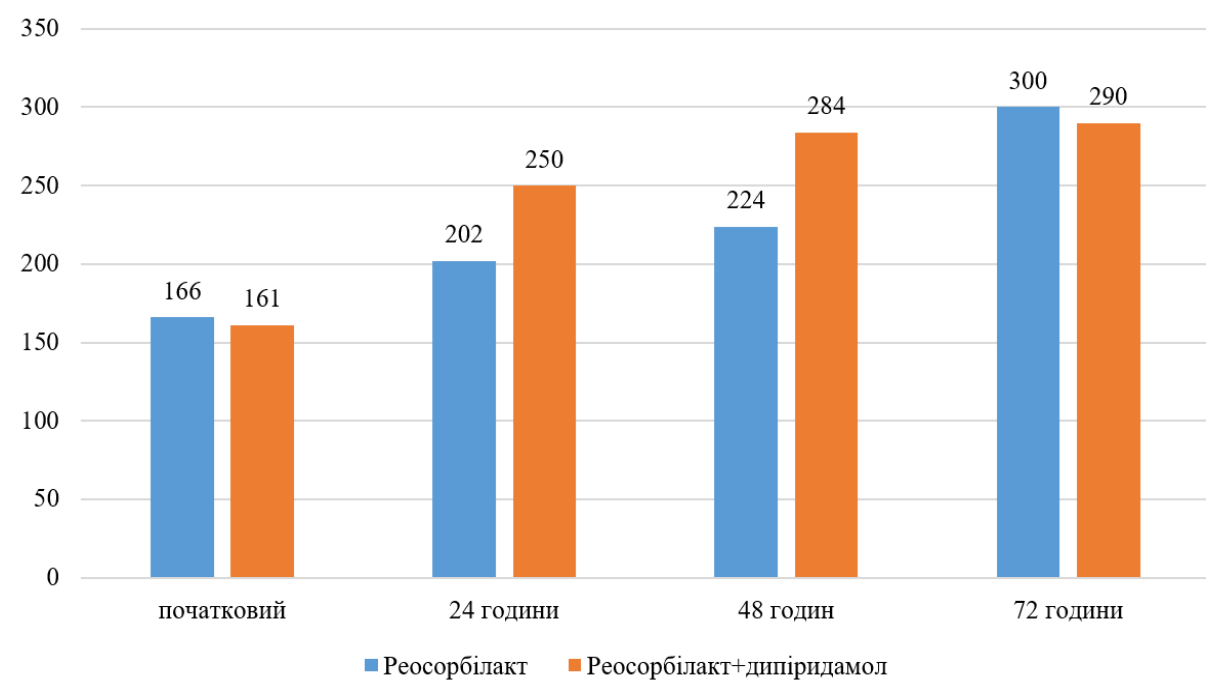

Рис. 4. Динаміка змін кількості тромбоцитів, Г/л, за застосування розчинів плазмозамінників

Враховуючи отримані дані, можна зробити резюме, Реосорбілакту та Дипіридамолу 0,5 \% у дозі 5 мл/кг що у патогенетичній терапії ускладнень гострого спонтанного бабезіозу собак з метою ліквідації розламаси тіла. Застосовані заходи дозволили відновити дів гемодинаміки та судинно-тромбоцитарного гемоспоказники до фізіологічних за 48 годин. тазу ефективнішою виявилася інфузія суміші розчинів 


\section{Висновки}

1. За гострого спонтанного бабезіозу собак як ускладнення розвивається субкомпенсований шок та синдром ДВЗ. Стан шоку та його ступінь визначаються достовірним дефіцитом об'єму циркулюючої крові.

2. Тромбогенна складова синдрому ДВЗ проявляється у порушеннях судинно-тромбоцитарного гемостазу, що характеризується зростанням спонтанної агрегаційної здатності еритроцитів та тромбоцитів, тромбоцитопенією споживання та збільшеним індексом змочування судинної стінки.

3. Застосування інфузій плазмозамінників $\epsilon$ невід'ємною складовою патогенетичної терапії субкомпенсованого шоку.

4. Інфузії суміші розчинів Реосорбілакту та Дипіридамолу мають добре виражений волемічний та дезагрегаційний ефект, за якого досягається відновлення гемодинамічних параметрів і показників судинно-тромбоцитарного гемостазу до фізіологічних впродовж 48 годин.

5. Рекомендовано застосування суміші розчинів складу: Реосорбілакт 100 мл + Дипіридамол 0,5 \% 4 мл, у дозі 5 мл/кг маси тіла тварини на добу впродовж трьох діб.

Перспективи подальших досліджень полягають у створенні комплексних схем патогенетичної терапії важких ускладнень за гострого спонтанного бабезіозу собак.

\section{Відомості про конфлікт інтересів}

Автори стверджують про відсутність конфлікту інтересів.

\section{References}

Bennett, J. S., Berger, B. W., \& Billings, P. C. (2009). The structure and function of platelet integrins. J Thromb Haemost, 7(1), 200-205. doi: 10.1111/j.15387836.2009.03378.x.

Birkhahn, R. H., Gaeta, T. J., Terry, D., Bove, J. J., \& Tioczkowski, J. (2005) Shock index in diagnosing early acute hypovolemia. Am. J. Emergency Medicine, 23(3), 323-326. doi: 10.1016/j.ajem.2005.02.029.

Dubova, O. A. (2016). Shock and DIC-syndrome as a pathogenetic axis of dogs babesiosis. Scientific Messenger of Lviv National University of Veterinary Medicine and Biotechnologies, 18(2(66)), 70-73. doi: 10.15421/nvlvet6615 (in Ukrainian).

Dubova, O. A., Feshchenko, D. V., Goralska, I. Yu., Duboviy, A. A., Zghozinska, O. A., \& Chala, I. V. (2020). Plasma replacement solutions in the intensive care unit of shock for acute spontaneous canine babesiosis. Scientific Messenger of Lviv National University of Veterinary Medicine and Biotechnologies. Series: Veterinary sciences, 22(99), 38-44. doi: 10.32718/nvlvet9906 (in Ukrainian).

Dubova, O.A., Feshchenko, D. V., Bakhur, T. I., Zghozinska, O. A., Antipov, A. A., Rublenko, S. V., Goncharenko, V. P. Shahanenko, R. V., \& Shahanenko, V. S. (2020). Disseminated intravascular coagula- tion syndrome as a complication in acute spontaneous canine babesiosis. Mac Vet Rev, 43(2), 141-149. doi: 10.2478/macvetrev-2020-0027.

Eichenberger, R. M., Riond, B., Willi, B., HofmannLehmann, R., \& Deplazes, P. (2016) Prognostic Markers in Acute Babesia canis Infections. J Vet Intern Med., 30(1), 174-82. doi: 10.1111/jvim.13822.

Guly, H. R., Bouamra, O., Spiers, M., Dark, P., Coats, T., \& Lecky, F. E. (2011). Vital signs and estimated blood loss in patients with major trauma: Testing the validity of the ATLS classification of hypovolaemic shock. Journal Resuscitation, 82(5), 556-559. doi: 10.1016/j.resuscitation.1011.01.013.

Holovakha, V. I., Piddubnyak, O. V., Bakhur, T. I., Vovkotrub, N. V., Antipov, A. A., Anfiorova, M. V., Gutyj, B. V., Slivinska, L. G., Kurdeko, O. P., \& Macynovich, A. O. (2018). Changes in erythrocytopoesis indices in dogs with babesiosis. Regulatory Mechanisms in Biosystems, 9(3), 379-383. doi:10.15421/021856.

Irwin, P. J. (2010) Canine babesiosis. Vet. Clin. North Am, Small Anim. Pract., 40, 1141-1156. doi: 10.1016/j.cvsm.2010.08.001.

Jarec, Ju. I., \& Novikova, I. A. (2014). Laboratornye metody ocenki sistemy gemostaza: ucheb.-metod. posobie dlja studentov 4 kursa medikodiagnosticheskogo fakul'teta med. vuzov. Gomel': GomGMU (in Russian).

Kirtz, G., Leschnik, M., Hooijberg, E., Tichy, A., \& Leidinger, E. (2016) In-clinic laboratory diagnosis of canine babesiosis (Babesia canis canis) for veterinary practitioners in Central Europe. Parasit Vectors, 9(1), 336. URL: https://pubmed.ncbi.nlm.nih.gov/22526812.

Köster, L. S., Lobetti, R. G., \& Kelly, P. (2015). Canine babesiosis: a perspective on clinical complications, biomarkers, and treatment. Vet Med (Auckl), 6, 119128. doi: 10/2147/VMRR.S60431.

Kutafina, N. V., \& Zavalishina, S. Y. (2012). Functioning mechanisms of vascular-platelet hemostasis. RUDN Journal of Ecology and Life Safety, 1, 30-37. URL: http://journals.rudn.ru/ecology/article/view/12380.

Levi, M. (2018). Disseminated Intravascular Coagulation. In: Hematology ( $7^{\text {th }}$ Ed. $), \quad 2064-2075$. doi: 10.1016/B978-0-323-35762-3.00139-6.

Nathan, H. L., Cottan, K., Hezelgrave, N. L., Seed, P. T. et al. (2016) Determination of Normal Ranges of Shock Index and Other Haemodynamic Variables in Immediate Postpartum Period: A Cohort Study. PloS ONE, 11(12), e0168535. doi: 10.1371/journal.pone.0168535.

Pacagnella, R.C., Souza, J.P., Durocher, J., Perel, P., Blum, J., Winikoff, B., \& Gülmezoglu, A. M. (2013). A Systematic Review of the Relationship between Blood Loss and Clinical Signs. PloS ONE, 8(3): e57594. doi: 10.1371/journal.pone.0057594.

Schorn, M. N. (2010). Measurement of blood loss: review of the literature. Journal of Midwifery Womens Health, 55(1), 20-27. doi: 10.1016/j.jmwh.2009.02.014.

Soroka, N. M., Dubova, O. A., \& Yaremenko, D. O. (2005). Sposib vyznachennia obiemu tsyrkuliuiuchoi krovi u sobak. Deklarats. patent 10707U Ukraina, MPK A61V5/0275: zaiavnyk i patentovlasnyk Nats. 
ahrar. un-t. № u2200505490; zaiavl. 08.06.2005; data publik. 15.11.2005; biul. № 11 (in Ukrainian).

Tvedten, H. (2004). Reference Values. In: Small Animal Clinical Diagnosis by Laboratory Methods, Willard, M.D. and H. Tvedten (Eds.) $4^{\text {th }}$ Edn., Elsevier, Missouri, USA, 417-419. doi: 10.1016/B0-72-1689035/50025-2.

Tyutyumova, E., Solovyeva, E., Karneev, A., \& Dzhutova, E. (2019). The mechanisms for activation of a vascular platelet component of hemostasis in the stroke recovery period and the ways of their correction. Neurology, Neuropsychiatry, Psychosomatics, 11, 72-78. doi: 10.14412/2074-2711-2019-1-72-78.

Wiseman, S., Marlborough, F., Doubal, F., Webb, D., \& Wardlaw, J. (2013). Blood Markers of Coagulation, Fibrinolysis, Endothelial Dysfunction and Inflammation in Lacunar Stroke versus Non-Lacunar Stroke and Non-Stroke: Systematic Review and Meta-Analysis. Cerebrovascular diseases (Basel, Switzerland), 37, 64-75. doi: 10.1159/000356789. 